\title{
Pemanfaatan Teknologi Android Untuk Deteksi Dini Penyakit Jantung Dan Kardiovaskular
}

\author{
Fitrianingsih" ${ }^{*}$, Elisma², Fatnur Sani K, Diah Tri Utami4, Mia Prajuwita ${ }^{5}$ \\ 1. Jurusan Farmasi, Fakultas Kedokteran dan Ilmu Kesehatan, Universitas Jambi, Jambi \\ 2 Jurusan Farmasi, Fakultas Kedokteran dan Ilmu Kesehatan, Universitas Jambi, Jambi \\ 3 Jurusan Farmasi, Fakultas Kedokteran dan Ilmu Kesehatan, Universitas Jambi, Jambi \\ 4 Jurusan Farmasi, Fakultas Kedokteran dan Ilmu Kesehatan, Universitas Jambi, Jambi \\ 5 Jurusan Farmasi, Fakultas Kedokteran dan Ilmu Kesehatan, Universitas Jambi, Jambi \\ Jurusan Farmasi, Fakultas Kedokteran dan Ilmu Kesehatan, Universitas Jambi, J. Letjen Suprapto No.33, Telanaipura, Kec. Telanaipura, Kota \\ Jambi, Jambi 36361, Telp (0741) 60246 \\ Email: fitrianingsih@unja.ac.id \\ DOI: $10.18196 / p p m .39 .122$
}

\begin{abstract}
Abstrak
Tingginya angka prevalensi penyakit jantung dan kardiovaskular sangat erat kaitannya dengan penyebab kematian tertinggi di In donesia. Hal ini bisa dicegah dengan deteksi dini penyakit jantung dan kardiovaskular sehingga bisa menghindari faktor resiko penyebab terjadinya penyakit tersebut. Salah satu upaya dan langkah praktis di era globalisasi saat ini adalah pemanfaatan teknologi android berbasis kesehatan untuk deteksi dan monitoring gejala klinis dari penyakit jantung dan kardiovaskular. Target utama pengabdian ini adalah civitas akademika di FST Unja. Diketahui potensi penggunaan smartphone di kalangan civitas akademika sangat tinggi tetapi untuk penggunannya dalam kesehatan masih banyak yang belum mengetahui dan belum optimal. PPM ini bertujuan untuk meningkatkan pengetahuan dan pemahaman mengenai pentingnya deteksi dini penyakit jantung dan kardiovaskular serta pemanfaatan teknologi android dalam optimalisasi kualitas kesehatan civitas akademika FST Unja. Metode yang dilakukan dalam program PPM ini yaitu dengan metode observasi, pendataan dan pelaksanaan melalui kegiatan penyuluhan disertai demo penggunaan aplikasi kesehatan pada smartphone dan evaluasi. Hasil dari kegiatan PPM ini adalah meningkatnya pengetahuan dari civitas akademika sebesar $80 \%$ serta mampu mengoperasionalkan penggunaan aplikasi kesehatan berbasis Android pada smartphone untuk mengetahui gejala klinis dari penyakit jantung dan kardiovaskular. Kegiatan ini berkontribusi merealisasikan dan menyosialisasikan program pemerintah "Heart-Healthy Environment" atau "Lingkungan Sehat bagi Jantung".
\end{abstract}

Kata Kunci: civitas akademika, jantung, kardiovaskular teknologi android

\section{Pendahuluan}

Penyakit jantung dan kardiovaskular menjadi momok yang menakutkan bagi masyarakat. Fenomena kasus kematian mendadak beberapa selebriti di Indonesia di awal tahun 2020 sebagai akibat over aktivitas dan kurangnya istirahat menjadikan kasus penyakit jantung dan kardivaskular ini sebagai silent killer yang semakin harus dideteksi sejak awal agar tidak menyebabkan peningkatan jumlah angka kematian. Berdasarkan data yang dilaporkan oleh PUSDATIN (2014) angka prevalensi penyakit jantung koroner pada tahun 2013 sebesar $0,5 \%$ atau sekitar 883.447 orang. Diketahui juga penderita penyakit jantung koroner, gagal jantung, dan strok banyak ditemukan pada kelompok umur 45-54 tahun, 55-64 tahun, dan 65-74 tahun. Berdasarkan diagnosis/gejala, penyakit jantung koroner, gagal jantung, dan strok juga banyak ditemukan pada penduduk kelompok umur 15-24 tahun (Kemenkes RI, 2014). Melihat kondisi prevalensi tersebut salah satu upaya deteksi dini tercepat dan sederhana adalah dengan pemanfaatan teknologi android. Aplikasi berbasis android pada smartphone yang saat ini sudah menjadi kebutuhan sekunder dan lifestyle masyarakat karena pengaruh modernisasi ini masih belum termanfaatkan sepenuhnya. Mengingat kelompok umur yang rentan terkena serangan jantung dan kardiovaskular adalah kelompok produktif (remaja hingga dewasa) maka pada tema pengabdian kali ini ingin mengetahui sejauh mana penggunaan aplikasi kesehatan berbasis android dan mendemonstrasikan penggunaan aplikasi ini pada civitas akademika Universitas Jambi khususnya pada Fakultas Sains dan Teknologi.

Universitas Jambi (Unja) merupakan salah satu perguruan tinggi di Indonesia yang terletak di Pulau Sumatera, Provinsi Jambi khususnya. Unja merupakan perguruan tinggi non-PTNBH kriteria madya (A) yang terdiri atas 15 fakultas, 89 Program studi, pada tahun 2020 ini memiliki sumber daya manusia (civitas akademika) dengan jumlah dosen (tenaga pengajar) sebanyak 1083 orang (838 orang 
PNS, 245 orang non-PNS) dalam hal ini dosen berjabatan fungsional asisten ahli sebanyak 110 orang, lektor 260 orang, lektor kepala 295 orang dan guru besar sebanyak 37 orang dengan jumlah mahasiswa sebanyak 24.911 orang. Adapun civitas akademika lainnya adalah tenaga kependidikan yang berjumlah sebanyak 881 orang (256 PNS, 625 non-PNS) (Unja, 2020). Salah satu fakultas baru yang menjadi fakultas favorit pilihan calon mahasiswa baru berdiri pada tahun 2012, terdiri dari 13 prodi, dengan jumlah dosen sebanyak 200 orang dan mahasiswa 2.500 orang (FST Unja, 2020). Program studi farmasi merupakan prodi dengan peminatan tertinggi di FST Unja dengan total mahasiswa sebesar 220 orang. Melalui penelusuran data statistik Unja secara online tersebut dan hasil observasi di lapangan diketahui potensi penggunaan smartphone android/iphone di kalangan civitas akademika Unja sangat tinggi khususnya pada mahasiswa farmasi dengan persentase sebesar 100\% (220 orang mahasiswa). Oleh karena, hal ini berguna sekali dalam menunjang kelancaran komunikasi civitas akademika dan proses belajar mengajar terutama penyampaian informasi perkuliahan sehingga keseluruhan mahasiswa farmasi memiliki smartphone android/iphone tersebut. Hal ini pula yang menjadi tujuan utama dari kegiatan pengabdian ini, yaitu memaksimalkan potensi farmasi dalam membantu meningkatkan kualitas kesehatan masyarakat (civitas akademika FST Unja) melalui deteksi dini penyakit jantung dan kardiovaskular dengan teknologi berbasis kesehatan.

Salah satu bentuk respon tanggap penyakit jantung dan kardiovaskular terhadap data di atas dari pemerintah adalah program "Heart-Healthy Environment" atau "Lingkungan Sehat bagi Jantung" yang dicanangkan oleh Kementerian Kesehatan RI bertujuan untuk menurunkan risiko penyakit kardiovaskular bagi individu, keluarga, dan orang sekitar. Hal ini dilakukan, dalam rangka mengendalikan peningkatan kejadian penyakit, kematian dan kecacatan yang disebabkan penyakit kardiovaskuler, sehingga diperlukan upaya pencegahan dengan meningkatkan kesadaran masyarakat dengan mengenali gejala dan risiko penyakit kardiovaskular sehingga dapat menentukan langkahlangkah pencegahan yang tepat (Kemenkes RI, 2014). Upaya lainnya adalah sosialisasi hidup CERDIK (Cek kesehatan secara berkala, Enyahkan asap rokok, Rajin beraktifitas fisik, Diet yang sehat dan seimbang, Istirahat yang cukup dan Kelola stress). Selain itu, sangat disarankan pengukuran tekanan darah dan pemeriksaan kolesterol rutin atau minimal sekali dalam setahun di Pobindu PTM/Fasilitas Pelayanan Kesehatan (Kemenkes RI, 2020). Untuk itu, diperlukan kolaborasi secara holistik dari tenaga kesehatan salah satunya apoteker.

Kegiatan pengabdian yang bertema pemanfaatan teknologi android untuk deteksi dini penyakit jantung dan kardiovaskular belum pernah ada sebelumnya. Oleh karena itu, pelaksanaan kegiatan PPM ini menjadi penting untuk dilaksanakan guna tercapainya visi Unja yakni $A$ World Class Entrepreneurship University (Pasal 25, Permenristekdikti No.41 Tahun 2018) dengan menciptakan SDM unggul dan pemberdayaan teknologi (penguatan TIK dalam pendidikan) sebagai strategi untuk mengatasi permasalahan yang dihadapi. Salah satu misi Unja adalah pengembangan technopreneuership berkualitas sesuai dengan sumber daya alam lokal dan lingkungan (Unja, 2020). Berdasarkan analisis situasi di atas, maka perlu dilakukan upaya untuk meningkatkan pemahaman dan pengetahuan mengenai bagaimana mendeteksi penyakit jantung sejak dini dan memonitoringnya dengan menggunakan teknologi android yaitu aplikasi (software) kesehatan seperti Health App secara aplikatif.

\section{Metode Pelaksanaan}

Metode yang digunakan dalam kegiatan pengabdian ini meliputi :

1. Observasi (tim melakukan observasi dan wawancara mengenai kondisi civitas akademika Fakultas Sains dan Teknologi Universitas Jambi. Tim awalnya bertemu dengan Dekan Fakultas Sains dan Teknologi Universitas Jambi dan perwakilan dari Himpunan Mahasiswa Fakultas Sains dan Teknologi Universitas Jambi yaitu Ketua Himpunan Mahasiswa Farmasi. Dari observasi awal tersebut, selanjutnya tim pengusul melakukan wawancara terkait kondisi kesehatan fisik terutama riwayat penyakit jantung dan kardiovaskular dari civitas akademika Fakultas Sains dan Teknologi Universitas Jambi).

2. Pendataan (Tim pengusul mendata berapa sebenarnya jumlah civitas akademika Fakultas Sains dan Teknologi Universitas Jambi).

3. Menyiapkan materi untuk penggalakan/penyuluhan dan pelatihan (setelah mendapatkan data yang jelas tentang civitas akademika Fakultas Sains dan Teknologi Universitas Jambi yang memiliki 
riwayat penyakit jantung dan kardiovaskular ataupun yang tidak, maka tim pengusul menyiapkan sejumlah materi untuk penyuluhan dan pelatihan).

4. Penyuluhan dan demo penggunaan aplikasi software kesehatan berbasis android yang terdapat pada smartphone (mitra diberi penggalakan/penyuluhan terkait pengetahuan tentang masalah gangguan kesehatan, penatalaksanaan penyakit jantung dan kardiovaskular).

\section{Hasil dan Pembahasan}

Kegiatan PPM ini adalah untuk memberikan pengetahuan tentang pemanfaatan teknologi android untuk deteksi dini penyakit jantung dan kardiovaskular pada civitas akademika Fakultas Sains dan Teknologi Universitas Jambi dan mengenali gejala klinis dan faktor resiko dari penyakit tersebut. Dari pengabdian masyarakat yang diberikan kepada civitas akademika Fakultas Sains dan Teknologi Universitas Jambi, partisipan bertambah pengetahuannya, karena telah diberikan edukasi tentang pemanfaatan teknologi android yaitu aplikasi kesehatan pada smartphone, gejala klinis dan faktor resiko dari penyakit jantung dan kardiovaskular.

Kegiatan PPM dilakukan secara virtual (online) dikarenakan situasi pandemi covid-19 yang terjadi di seluruh belahan dunia. Perlu dilakukan penyesuaian adaptasi pelaksanaan kegiatan PPM ini dengan tetap melaksanakan protokol kesehatan Covid-19. Kegiatan PPM ini dilaksanakan dengan kolaborasi mitra dari Himpunan Mahasiswa Farmasi (HIMAFAR) Unja. Kegiatan ini diselenggarakan secara virtual melalui aplikasi ZOOM Cloud Meetings dan live streaming pada channel YouTube http://www.youtube.com/watch? $\mathrm{v}=\mathrm{OBbgqR} 5 \mathrm{RxH} 0$ yang diikuti oleh 134 peserta yang terdiri atas kalangan mahasiswa, pegawai, tenaga kependidikan, dan dosen. Penyelenggaraan PPM ini bekerjasama dengan Himpunan Mahasiswa Farmasi (HIMAFAR) Fakultas Kedokteran dan Ilmu Kesehatan seperti terlihat pada Gambar 1.
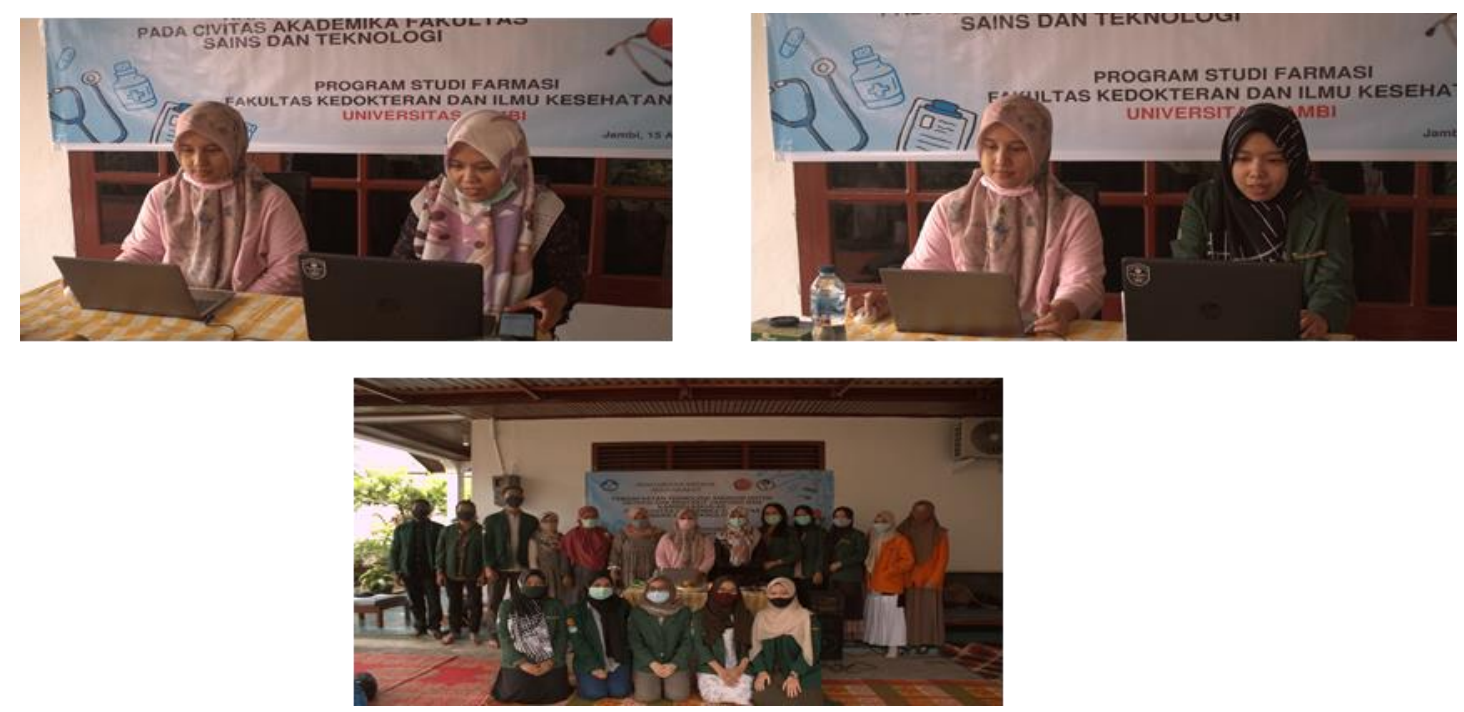

Gambar 1. Kegiatan PPM

Analisis tingkat pemahaman masyarakat dalam hal ini civitas akademika Universitas Jambi dilakukan dengan memberikan beberapa pertanyaan terhadap para partisipan secara virtual. Hasil analisa data dilakukan secara deskriptif dalam bentuk persentase kemampuan peserta dalam menjawab pertanyaan kuis yang diberikan. Dari data tersebut terlihat adanya peningkatan pemahaman sebelum dan sesudah pelatihan diberikan. Diketahui bahwa sebelum dilakukan pelatihan persentase pemahaman partisipan sebesar $40 \%$ dan setelah mengikuti pelatihan, mengalami peningkatan menjadi $80 \%$. Hal ini menunjukkan adanya pengaruh positif dari pelaksanaan kegiatan PPM ini. 


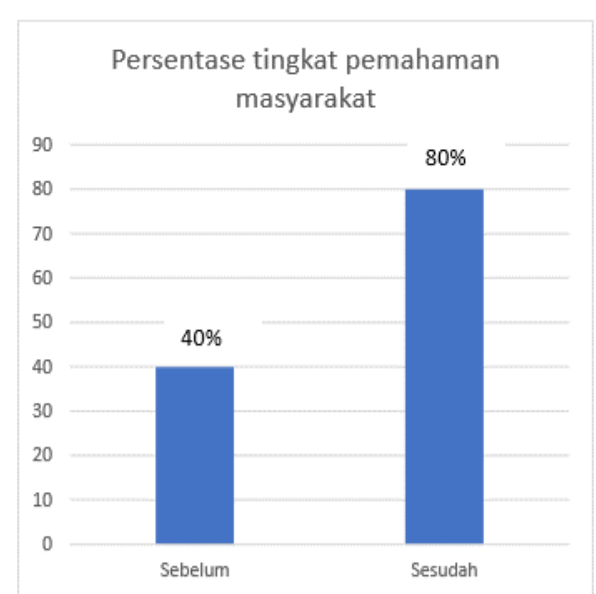

Grafik 1. Persentase tingkat Pemahaman Sebelum dan Sesudah Pelatihan

Kontribusi dari program pengabdian ini diharapkan akan meningkatkan kualitas kesehatan civitas akademika Fakultas Sains dan Teknologi Universitas Jambi, sehingga realisasi program pemerintah "Heart-Healthy Environment" atau "Lingkungan Sehat bagi Jantung" dapat tercapai dengan menyosialisasikan hidup CERDIK (Cek kesehatan secara berkala, Enyahkan asap rokok, Rajin beraktifitas fisik, Diet yang sehat dan seimbang, Istirahat yang cukup dan Kelola stres).

\section{Simpulan}

Kegiatan PPM yang telah dilakukan ini mampu meningkatkan pemahaman civitas akademika Universitas Jambi dengan persentase pemahaman $80 \%$. Hal ini merupakan wujud nyata dari kontribusi kegiatan ini dalam merealisasikan dan mensosialisasikan program pemerintah "Heart-Healthy Environment” atau "Lingkungan Sehat bagi Jantung”.

\section{Ucapan Terima Kasih}

Terima Kasih kepada Universitas Jambi melalui Lembaga Penelitian dan Pengabdian Masyarakat Universitas Jambi yang telah mendanai kegiatan PPM ini serta Fakultas Sains dan Teknologi dan Himpunan Mahasiswa Farmasi Universitas Jambi yang telah menjadi mitra dalam kegiatan ini.

\section{Daftar Pustaka}

FST Unja. (2020). Transformasi Fakultas Sains dan Teknologi (FST) Terobosan menuju Pendidikan Berkualitas - Universitas Jambi. Jambi. Retrieved from https://fst.unja.ac.id/

Kemenkes RI. (2014). Infodatin Jantung. Jakarta.

Kemenkes RI. (2020). Penyakit jantung penyebab kematian tertinggi, kemenkes ingatkan cerdik. Kementerian Kesehatan RI, pp. 1-2.

Unja. (2020). Statistik UNJA. Jambi. Retrieved from https://dss.unja.ac.id/ 